\title{
SOCIAL STUDIES LEARNING FOR THE DEVELOPMENT OF EMPATHIC AWARENESS
}

\author{
Erlina Wiyanarti ${ }^{1}$
}

\begin{abstract}
The background of this research is the tendency of emphatic awareness learning that is being overlooked in the social studies in schools. The main problem addressed in this research is the social studies learning for the development of emphatic awareness of student of elementary school level in Bandung.The objectives of this research are (1) to design a model of social studies learning program for the development of emphatic awareness of fifth-grade students of elementary school in Bandung, (2) to test the effectiveness of the learning program, and (3) to identify difficulties encountered by elementary school teachers in developing social studies learning for the development of emphatic awareness of fifth-grade students. The methodology of this research is using multi method approach with two-phase designs model or double research strategy. After the research is conducted, based on analysis and discussion of the phase 1 result of limited testing, a stable emphatic awareness learning model was found, then focusing revision in cycle. The early model in product testing was conducted by using pair t-sampling. The result shows that social studies learning model using story telling method is effective in developing emphatic awareness of student in all indicators. The difficulties faced by teachers are more related to the level of understanding of emphatic awareness, creativity, and innovation level which are not optimum. Based on the analysis and discussion and the result of the research, the general conclusion is the development study have met the objective. Emphatic awareness learning model can be applied through planing management and implementation of learning through storytelling method which have high applicability rating with a favorable result and has good implication theoretically and practically. The proposed recommendations are beneficial for model application and for further studies.
\end{abstract}

Key Word: empathic awareness, social studies learning

\section{Introduction}

The history of the society always contains the tendency to destroy its humanity. The tendency seems to have been inherent in the structure of human genesis. The practice of violent culture is an inseparable phenomenon from the human historicity. (Colombijn in Fortuna, 2005). The beginning of this $21^{\text {st }}$ Century was indicated by the tendency towards the attenuation of humanity, erosion of religious spirit, disorientation of moral-religious, also the weakening of humanity

1 Dr. Erlina Wiyanarti, M.Pd, lecturer of History Education, Faculty of Social Science Education, Indonesia University of Education. For academic interest, the author can be contacted at Jl. Dr. Setiabudhi 229 Bandung, email: erlina.wiyanarti93@gmail.com. 
values that in turn trigger the increase of violence, alienation, mental depression and the awakening of tribalism or mentality that consider in the superiority of one's own race or group, even in a condition that is capable of losing a nation's cultural identity, which is a human's highest point of concern in the global battle. The period is marked by the number of violent explosion stimulated by ethical, religious, cultural or territorial dispute (Toeffler, 1992; Miall, Ramsbotham dan Woodhouse, 2000; Fortuna et al, 2005), therefore it is not surprising that Dalai Lama (1999:20-27) said that the $21^{\text {st }}$ century has become the century of humanity crisis indicated by the increasing violence and the spread of conflicts ending in war.

One of the basic issues that must be attempted by the society in reconstructing its culture in this $21^{\text {st }}$ Century, according to Capra (1998) is the effort to reduce violence, chaos, and other interferences that appear during the eras of social changes. In order to build such society, it is necessary to have diverse efforts to augment the quality of life in various aspects, particularly in education. As citizen of the world, Indonesia has a duty to try to find the solutions for those problems. An effort that must be undergone by the nation is to promote the importance of education in humanity values awareness.

An ideal education, in fact, is always directed to future society development following humanistic process that emphasizes on potential development specific to every person as a human being ( $\mathrm{O}^{`} \mathrm{Neil}$ 2002: 466). Education does not only prepare one to enter a future that probably will bring out new values, but must also depart from the enactment of previous values as historicity that enables the continuity among generations of the society as support to the culture (Hasan (1995). Education is a human empowerment effort towards the development of human dignity which is the valence and dignity of human or humanizing human (Mastuhu, 2003; Sastrapratedja 2003). Social studies (IPS) at the Elementary Schools and Madrasah Ibtidaiyah (islamic elementary school, usually privately owned, though some receive subsidy from the Department of Religious Affairs) is ideally designed as devices and tools to direct, lead, and assist students to develop their self identity as citizens of Indonesia and citizens of the world who have commitment and awareness on humanity values in a pluralistic society, either nationally or globally through the achievement of knowledge, skills, attitude and values that are expressed in the habitual way of thinking and acting in order to sustain life, self adaption, and succes in the future (Depdiknas, 2004).

The developed process of social studies learning in schools have been too focused on intellectual aspects and have disregarded the development of the conscience aspects in self identity and manners of the students in their social lives. The alienation of students on humanity values that becomes their self identity and also identity of others in the learning process has been clear. The practice of value awareness learning in the form of empathic attitude and behavior are still deficient in schools. Referring to the thoughts of Hasan (1996) that is reinforced by Loomans and Loomans (2003), the weaknesses and gaps in the learning is 
based on the tendency to disregard the value aspects that can build the awareness the significan social knowledge in the daily lives of the students. Social knowledge learning is dominated by memorizing the facts and theoretical discussions that are never interrelated to the living society.

\section{Statement of The Problem}

Based on the analysis of condition, normative, historical, empirical, and perspective analyses, it is obvious that the problems have been faced by social studies learning is the learning process that in reality has been developed in to the humanity awareness that lives and advances in the society. In elementary schools, the foundation of problems have become more complex as the materials of the social studies learning that are abstract and imaginative must be taught to students who are still in the boundaries of the concrete and formal operational development level (Piaget in Hurlock, 1992). With the background and those considerations, the focus of this research will be directed to the development of learning model that can build the empathy of the students in elementary schools.

Learning as a systematic effort that consider academic and psychological aspects, consists of principal phases in each level of development planning, implementation and evaluation stages (Hamalik, 2002: 10). For the purpose of direction and research focus, therefore the first research problem was "what will the designs of the social studies learning effectively develop the empathic awareness of the fifth grade elementary students in Bandung?"

The success of a learning model can be viewed from the effectiveness of its execution. In order to view the potency extent of the referred social studies learning model as the device of empathetic attitude development, thus its effectiveness must be verified. Serving as a direction for this research. Therefore the formulated third problem was "are there any obvious differences in empathic awareness between the experimental and the control classes of the fifth grade elementary students."

In socializing the program through research and development, in this opportunity, teachers are facing several technical, academic and psychological difficulties. In order to obtain a clear illustration in the research on the difficulties faced, thus as guidance of the fourth research problem was formulated with the following question, "what difficulties are faced by elementary teachers in developing the social studies learning to advance the empathic awareness of the fifth grade of elementary school students in Bandung?"

\section{Objectives}

The general objective of this research is to discover or develop a social studies learning program as a device to develop empathic attitude of fifth grade 
elementary school students in Bandung. Meanwhile its specific purpose is to develop a social studies learning implementation program, to test the effectiveness of the social studies learning program, and to identify the obstacles faced by the teachers of the fifth grade of elementary school students in developing the social studies learning as the device for empathic attitude development of the students in Bandung.

\section{Research Method}

Based on the stipulated objectives, thus this research will be executed with a multi-method approach with the two - phase design model (creswell, 1994) or double research strategy (burgess and brannen, 2002). the two - phase design model basically combines two research designs, which combines the action research design (qualitative naturalistic) and the quasi experiment research design (quantitative-rationalistic), combining the research designs are conducted as an effort to prevent the tendency to obscure the complexity of research difficulties and to prevent ineffective decision makings. the study plot that the writer utilizes includes 3 main phases, they are: a. preliminary study, b. development phase with classroom action research approach, and c. product testing phase through experiment. based on the illustration of the experiment and control groups, therefore the experimental design testing are "posttest only control-group design "(millan and schumacher,2001:339; gall, gall and borg, 2003: 395), by using sample $t$-test paired hypothesis testing on spss 17.0 software. this trial test results will help discover the hypothesis findings, the researchers compares the value of $t_{\text {count }}$ with $t_{\text {table }}$. if $t_{\text {count }}>t_{\text {table }}$ thus $h_{o}$ is rejected and $h_{1}$ is accepted, and vice versa. for $\mathrm{df}$ $\mathrm{n}-1=89$ with a significant standard: alfa $(\alpha)=0,05$.

\section{The Findings of Model Development}

The findings of the analysis and discussions of the first phase research show that the general illustrations on the social studies learning condition based on humanity values through questionnaires for elementary teachers in Bandung have been capable of providing initial comprehension to the researchers on the actual conditions of social studies learning in the field. Based on the analysis towards the response addressed in the questionnaire, it can be concluded that the teachers realize that value awareness learning can be developed through the social studies learning. In the initial observation phase, an intensive communication process was built and signifies as an initial phase of developing participative collaboration among the researcher, teachers and students. Two points were agreed upon these phases that are the implementation of teachers' training and class orientations as the basis for preparing an action plan.

The applied training can provide a positive contribution to improve the teachers' comprehension on the importance of empathic awareness learning in 
achieving the objectives of social studies teaching, particularly in the commitment development aspect and the awareness of social and humanity values, also social adaptability that is part of the pillar to form good citizens. Apart from that, this training has also enhanced the confidence of teachers as partner of the researcher in collaborating for the implementation of this study. Meanwhile, findings of the class orientation, either from RPP document studies or the learning process in class, have clearly showed that the value awareness, particularly empathy, has not been developed. The learning that has been developed is still oriented on the cognitive development of the students, which is also limited to the standard of cognitive at a low level. It has been one of the obstacles for developing empathic value learning and also the advancement and reinforcement of empathic awareness.

Based on the findings of analysis and discussions of action 1, it can be concluded that the significance of social studies learning model for the empathic awareness of the students through an integrated approach (VCT), discussion method through the film media has yet shown any significant effectiveness. Therefore, it can be said that the weakness of the learning model on Action One lies on the selection factor and development approach, the method and media of learning are inaccurate. Meanwhile in Action 2, the direct approach learning model through storytelling method supported by direct communication media, has effectively developed the empathic awareness of the students. Meanwhile in Action 3, which serves as reinforcement, the model remains effective in developing the empathic awareness of the students.

\section{The Findings of Model Testing}

Different to the research in the first phase that aims to develop the learning model through action cycles, therefore in the second phase, field operational testing is conducted with the main purpose to conduct a feasibility test of the empirical model through the t-test statistic. Testing was conducted in four schools, 2 control classes, SDN Babakan Surabaya and SDN Cidadap 2, and 2 experimental classes SDN Banjarsari 3 and SDN Kresna. The result of statistical calculations on the trial run phase (phase 2 research) can be viewed in following the two tables.

Based on the $t$ test results on the above table, it shows that in the product testing, there is an average result of the entire sub variable of empathic awareness, in the condition between the experiment and control classes discrepancies occurs, which is indicated by the post test results, in which the average score of the experiment class are all higher than the control class. This means that the given treatment through the learning model by the developed storytelling method can provide significant results. Therefore the proposed working hypothesis is accepted and zero hypothesis is rejected, on a significance standard of 0.05. This means that the learning model with the storytelling method, which was implemented 
in the experiment class in the form of treatment, that is capable of displaying its effectiveness in order to achieve the objective, which is to increase the empathic awareness of the students. Other facts that are disclosed from the findings are described in the table.

Notifying the deviation standard score in the test table, it is shown that either pair 1 up to pair 2 results in a small figure. This signifies that even though treatment was conducted in the experiment school, in fact the treatment does not cause a significant score discrepancy between the top class students and the low class students.

In the product testing phase, the tested working hypothesis is accepted and the zero hypothesis is rejected. This means that there is a discrepancy in the entire sub variable that is involved. It shows that the treatment given through the learning method by the developed storytelling method is capable to provide significant results, in the learning setting of the experimental school. The significance shown by the entire sub variable has verified that the working hypothesis that has mentioned a discrepancy between the post test results of the experiment and control classes is accepted. Therefore, it can be understood that the learning model through using the storytelling method which is implemented in providing treatment has proven to be capable in enhancing the empathic awareness of the students.

Other significant result of the statistical test findings is the storytelling method that has been confirmed effective on the following aspects:

(a) Capable in providing thoroughfull comprehension to the students of SDN Banjarsari 3 and SDN Kresna, on the topic of the struggle of Dewi Sartika; (b) Capable in providing profound comprehension on the struggle of Dewi Sartika in fighting for women, also giving the touch that is essential as of fellow human beings, thus encouraging the students to make choices that embodies empathic awareness attitude of high quality; (c) it is Capable of developing respect on the struggling choices and tolerance attitude of Dewi Sartika as a hero who fought for the independence of women, and also growing a compassion attitude towards Dewi Sartika as fellow men who could sense happiness, love and forgive, have fear, sadness, anger, concerned, weary and overwhelmed; (d) This method has enhanced the forming of reflective attitude which contains empathy, so the students have their ability to share the spirit of Dewi Sartika who worked hard and firmly fought for the progress of women by building "Sakola Istri", and this spint has fostered motivation within student to study hard and diligently. Therefore, after understanding, realizing, and be coming conscience to the love and sacrifice of Dewi Sartika beginning from when she was young until she became an adult to always promote education, that has made one encouraged to grow genuine intentions and to send prayers to Dewi Sartika, and as a form of their appreciation, to grow the desire to continue her aspirations and study even more diligently.

The significant effectiveness from the social studies learning model for the empathic awareness of the students by the storytelling method with the historical 
theme in this research, reinforces suggestions launched by Hoodless (1998) and Bage (1996: 49), mention that the storytelling method in the social studies learning, particularly interrelated with the historical theme, has an important role. It can even be stated as "the heart of the history teaching", which can be developed into multi aspects and persfective in any level of education The storytelling method with using the topic of Dewi Sartika theme in the entire sub-variable has proven to be effective in building the empathic awareness, either in cognitive, affective or connotative dimensions of the students.

Meanwhile the obstacles faced by the teachers in developing the social studies learning model for empathic awareness with the storytelling method, were based on the interview results and direct observation in the learning process, that are interrelated with the mental attitude of the teachers who have yet realized that the empathic attitude learning can be developed, either in the learning plan design or in the learning process in the class. The next obstacle was that very few teachers who could comprehend the importance of the empathic attitude that could be developed in the social studies learning as one of the essential power value from the humanity power value. The third obstacle was the creativity aspect that is yet optimum from the teachers to explore and elaborate the learning method that they have developed. The technical difficulty was the time that the teachers must spare for training their ability to tell empathic stories effectively.

\section{Empathic Awareness Learning Model as Research Findings}

This model finding is a result of perfecting and refining the hypothesis model that has been tested in the process above. The perfecting and refining was conducted based on collective data and suggestions, either through a validation process in the form of class action research (PTK), or empirical data obtained through empirical testing in the form of experimental research in phase two.

\section{Model Component}

Model component consists of two aspects which are model assumptions and approach model implementation.

\section{Model Assumptions}

\section{The Facts of Social Studies Learning in the Humanistic-Holistic Approach}

Humans with their humanity in the humanistic views are the central of reality, therefore anything that exists in the reality must be returned to the humans (Baharuddin and Makin, 2007; Widiastono, 2004).The fact of humanity or humanism in the life of the Indonesian nation is firmly stipulated in Pancasila as the nations' way of life. According to Ki Hadjar Dewantara, the primary essence 
of Pancasila is humanity and from that thought, an illustration of the Divine according to the civil humanism, and nation is based on humanity, reflected in the sovereignty of the people bearing in mind the humanity, and the social justice in accordance with the demands for civil humanity.

The natural potential aspects related to the learning concept consists of the basic aspects owned by humans, which differentiates them from other beings, which are: instinct, mind and conscience. Ki Hadjar Dewantara referred to these natural potentials as "The Soul of Trisakti" which was empowered in the human soul. In general, it consists of "mind, senses and will". These three natural potentials are known in eastern psychology as aspiration, senses, and will (Dewantara, 1977: 451). Meanwhile, the domain theory that has been brought forward by Bloom and further developed together with other experts, proposes three domains that have become the leading natural potential of mankind which is classified in the cognitive, affective, and psychomotor domains (Bloom, 1986: Krathwohl, Bloom, Masia, 1964; Harrow, 1972).

The social studies learning as the development of the natural function of students contains a conception that as a perfecting effort and or heading toward perfection from multi aspects of natural potential exists within every human, and has been full and integrated with one another. The social studies learning as a part of the National Education has been derived from various social and humaniora knowledge, and has an important role in advancing the capability and competency of your generations as citizens of the nation, as stipulated in the SISDIKNAS legislations. Therefore, social studies learning has a strategic role in achieving the aspirations of the society, nation, and country.

The leading thread that appear and can be reinforced in the signification of humanistic and comprehensive social studies learning are social studies education developed to assist or guide the students with their natural multi potential for the purpose of advancing the capabilities in their comprehension, competition, attitude, feeling and characteristic holistically on the human relations as a social being with its environment, as a main foundation to be powerfull citizens and represented in integrative characteristics. Through the humanistic-holistic aspect social studies learning is expected to form individuals who are confident, aspect responsible and also capable of revealing themselves as good citizens with empathic disposition.

\section{Empathic Awareness As A Form of Life Skill}

Empathy in one issue is understood as equally by Hoffman (1978) and Ickes (1997). Both of them agree that empathy in the taxonomic psychological approach is a psychological symptom with a double characteristic, which integrates cognitive and affective domains. The integration according to Krathwohl, Bloom dan Massia (1964: 54) in their writing, is very feasible. This means the relationship of influencing each other from both domains is possible to be developed in the 
learning process. Apart from that, empathy can also be signified as emotional intelligence in the form of its capability in exploring other people's feelings, however it is still safeguarding several separations (Gordon, 2009: 37). Having empathy means one can feel what the others feel, without losing one's identity, one can feel the pain of others, yet one's feelings do not actually hurt others; one can feel the confusion, anger, fear, affection of others as if they occur as one's own feeling, yet one does not lose awareness that they are "as though" (Petterson, 1962:168; Decety dan Ickes, 2011). Therefore, the empathic awareness can be signified as the ability to view something from other people's point of view, and clearly comprehend the thoughts and feelings of other people by placing oneself in the psychological manual framework of the other person (Nasution, 1987:87; Kartono, 1987; Rakhmat, 1992: 32).

\section{Social Studies Learning for Empathic Awareness of Students Through the Storytelling Method}

Learning can be defined as a self actualization development process in making free yet guided decisions for a better and positive directions, based on the level of comprehension towards others that is arranged in a form of cognitive and affective structure that are continuously constructed with certain patterns and phases through interaction in a unique social network that is formed by a culture internal or external to the class. Therefore, the learning process of internal characteristics includes the accepted stimulus arrangement and adjusted with the cognitive and affective structures that are already possessed, such as memory, retention, information processing, emotions, and other psychological aspects that are directed at self actualization as well as building social skills, attitude, sensitivity or sharpness, either in the thinking ability, or the ease of one's conscience being touched by seeing and sensing all things (Nasution, 1987: 136; Gredler, 1991: 187; Winkel, 1996: 97).

Social studies learning can be effective through storytelling method assisting students in observing situations or issues, either in a contemporary or historical or past settings (NCSS, 1994: 9). Even though traditionally, storytelling is viewed as entertainment during leisure time. However, storytelling is then placed as a vital teaching tool as this strategy has been implemented by all cultures throughout the world for hundreds of years (Armstrong, 2002). Stories can carry enormous impacts on learning that in several matters are related to 'the direction' of children, which is related to the beliefs and personal values (Doddington dan Hilton (201: 125). The learning of storytelling fosters authentic involvement attempted by the teachers and students in activities, including thoughts and actions that encourage the formulation of an opportunity most likely for the process of sharing feelings and authentic experiences, mending and developing matters that are really important to the children. Stories have important roles in building the personalities and learning of children, (Semiawan (2008: 34), 
because they can penetrate into the instilling of implementation. The story telling method opens up a large opportunity for emotional involvement, comprehension and mental among the teacher telling the story and the students. Therefore, a two-sided experience is formed between the story teller and the child.

The role of the teacher in developing the story telling method is as the story teller. Story telling is the transfer of stories delivered to the audience or the listeners. Story telling is a natural art prior to become a skill. Natural story tellers have the tendency to be stronger compared to story tellers who completed school/ formal courses. The ability to tell a story well will not be the same; however this does not prevent a teacher to keep practicing diligently. The teachers must keep training themselves as reminded by Husband (1996: 92) that one should not look down on the role of teachers in the story telling method in learning history, as he said, "the way teachers describe the past is powerful element in the way pupils construct their own images of the past".

\section{Approach of the Learning Model}

The implementation approach of the learning model is based on learning that is focused on student activities, integrated affective learning, contextual approach of today, the past and prospective future, and thematic approach.

\section{The Purpose of Model Implementation}

Generally, the empathic awareness learning model has a purpose to assist students in developing tolerance values and compassion to fellow men as a foundation of empathic awareness. From a psychological aspect, this empathic awareness learning model intends to develop a meaningful empathic affective capability towards experience in empathic attitude and behavior that has been practiced in life. With this capability, the students are motivationally expected to become humans that are more humane with a wide tolerance attitude and profound compassion towards fellow men and are practiced in empathic behavior.

\section{Final Model Implementation in Learning}

The methods of the model as described in the previous segments are series of systematic procedures. Every phase supports the achievement of other objectives. In the event that it is implemented in the learning process in classes, therefore the procedural series can be detailed as follows:

(1) Introduction

This phase is a conceptual orientation related to the learning matters that are conducted with the purpose of students to comprehend the objective of learning and the expected indicator and also to create a conducive atmosphere in class for learning. The utilized method is the storytelling method that directs and touches the heart that is completed with self mollification of the entire class. 
(2) Identification and confirmation of empathic awareness

The purpose of this step is for the subject to recognize, comprehend and be conscience of the development of empathic awareness towards the behavior of the figure of the story. In this phase, the students are capable of identifying, in general, empathic behavior and its relations to intrapersonal and interpersonal capabilities, either in the dimension of life today, in the past and in the future. Apart from that, the students can feel the benefit of having empathy in understanding one self and others as the foundation in forming a harmonious and humane communication. This phase is conducted with storytelling technique with empathy.

(3) The interpretation and optimalization of empathic awareness

This phase is intended for the students to profoundly and calmly understand, realize, absorb and sense also to be conscience of the empathy that grows in their thoughts and feelings. The procedure to be implemented is granting an interval for students to calm themselves, which will be further be continued with a reflection guided by the teachers.

\section{The Weakness of the Final Model}

The first limitation, from the developing material substance on empathic awareness in the device of experts has yet to achieve a full agreement on the comprehension and significance of empathy. From these two big flows, comprehensions on empathy have developed; nonetheless, the difficulty for the researchers in Indonesia, as far as it is concerned, is that research related to empathy is very difficult to find.

The second limitation, interrelated with theoretical understanding that supports the research implementation. Understanding the study on empathy is relatively new. It started to become the centre of attention after Carl Rogers in the year 1957 lifted it as part of the therapeutical approach by using empathic communication.

Third limitation, The next difficulty is that the development of this model requires the ability and thorough comprehension on empathy by the teachers, and who also become the story tellers

\section{The Strengths of the Final Model}

The main strength of the final model can be implemented in the learning of elementary schools. Even in the proposed recommendation, the learning method can also be developed in various levels or education units,, as long as the implementation is executed by paying attention to the development of the students. Looking at the needs in the methodology of education, a simplified empathic awareness learning built by tolerance and compassion towards fellow men that is very abstract that simplifies its application in learning. The development of 
empathic awareness is very strategically developed in social studies learning. Considering that through social studies learning, young generations are lead, guided, and motivated to become citizens who have commitments on social values and human rights with its humanity. Experiencing all of the facts, it is necessary to contribute this learning method as one of the solutions to promote love and affection values and attitudes towards fellow men in the hope that living in harmony, peache and prosperity on earth.

\section{Conclusion}

In general this study has reached its objective that is to develop an empathic awareness learning model implemented through the plan management and implementation of learning through story telling method. It can also be generally concluded that the model which has been successfully developed has proven to be applicable in the fifth grade of elementary schools in Bandung. Therefore, it can be said that it contains a high level of applicability with quite satisfactory results. Details of the conclusions can be elaborated as follows:

a. The findings of the cyclical test of the limited and broad development with the PTK method as unraveled in the previous section, it shows a stable development towards a positive direction in a natural background or setting with revision focus on Action 2 Cycle on the limited development cyclical test The changes in the Action 2 Cycle up to the final cycle of the development and the refining of the model conducted systematically and logically commencing from Cycle 2 up to the final cycle on a broader development results in an initial model that was tested in second phase though the testing experiment.

b. The findings of the conducted $t$ test as mentioned in the previous chapters, shows a significant discrepancy on almost the entire sub variable of empathic awareness in the experiment class with the learning treatment through the storytelling method in the control class that did not receive the treatment. This means that the treatment given through the learning implementation through storytelling method has proven to be more effective in developing empathic awareness of the students. The entire sub variable from the empathic awareness variable, either with cognitive, affective, or connotative aspects, is significantly different between the experiment class and the control class.

c. The hypothetical testing in this research also shows that the level of empathic awareness of students is significantly different, between experiment class and control class.

With regard to the substance of empathic awareness learning model that has been developed, based on the conducted study, the conclusions are as follows:

a. The empathic awareness learning method is very relevant to the demands of the social studies learning for students, particularly for the fifth graders of elementary schools today. The phenomenon shown from the social studies learning all this time is the abandonment of empathic awareness development, 
bearing in mind and looking at the behavior of children, either at home, at school, or in the society nowadays shows the tendency of the reinforcement of non empathic attitudes, which evidently needs to be re-evaluated by searching for several alternatives of learning models that are considered relevant. This study is one of them, and in fact proven to be effective empirically.

b. This empathic awareness learning model, appears to have been effectively implemented by teachers in schools. This is verified empirically, either through cyclical or experimental testing.

c. The empathic awareness learning model achieved through this study has specificity, which is working at affective levels by benefiting from psychological concepts and theories, apart from other disciplines; something that is required in the social studies learning comprehensively and meaningfully. With affective levels, therefore this study is based on the assumptions that cognitive and co native aspects, particularly in comprehending the empathy concept and the desire for actions has been achieved by the students though the social studies subject at school.

d. The empathic awareness learning model achieved through this study, looking at its procedure, the implementation is quite simple, and therefore it has a high level of applicability. With a quite simple procedure, the teachers can easily implement this model.

\section{Implications of the Results 1. Theoretical Implications}

Findings of this research have confirmed that openness, wither from the teachers or the students enables the development of relations full of affection and integrity. Viewing the fact that empathy is related to a very refine aspect of humans, which are feelings on morale, emotions and humanity values that are good and noble and therefore it has been proven that relations that have been closely connected during the learning process significantly provides influence in obtaining valid effectiveness.

Effective empathic awareness is developed through direct communication learning model in the form of stories that can also serve as the device for the teachers to enter the comprehension and senses of the students from the perspective of the students. The penetrate into process operates in a normal, natural, exciting, and meaningful.

This study has discovered empirical facts that effective empathic awareness learning with a holistic humanistic approach, meaning that affection development is not signified as pure and sole efforts. The affective development in this research is part of the supernatural potential with holistic characteristics.

Comprehending the research findings has shown shows realistic empathic awareness learning that involves aspects of understanding the values and morale of the students, and therefore it is without doubt that the empathic learning will be effective it involves affective process development. Considering the level of 
development of elementary students are still at the concrete thinking, meanwhile empathic awareness, tolerance values and compassion towards fellow men are abstract concepts, therefore on this level direction, guidance, and leadership from teachers are necessary, in order to prevent misconception.

The findings of this study show that the theme or materials of empathic awareness learning development are in social studies learning device, which have confirmed to be effective when interrelated with daily human activities. With selected contextual story themes, either in human's life today or in the past in the scope of their daily lives, this model has proven to be effective in developing the awareness of students.

Therefore, a contextual thematical approach has become one of the characters of this model. Contextualization has confirmed to have facilitated the students in feeling and experiencing a more concrete learning process which existing in their daily lives.

The integration, either in approach, materials, methods, learning activities, evaluation, or procedural, has confirmed to be effective in developing the empathic awareness of the students. The integration has become one integrated whole in the planning or model implementation phases. Therefore the first phase is an integral part of the other phases in the learning system.

The approach of direct learning through direct communication as the media, an integrated aspect is very feasible to perform, considering the teachers in fact are living curriculums, therefore the aforementioned integration is part of the efforts in learning development for a more vibrant and meaningful for the students in achieving the objectives or displaying the indicator in accordance with the plan.

\section{Practical Implications}

The findings of this development also carry implications towards the execution of social studies learning in classes. Some of the implications are described as follows:

a. The empathic awareness learning model as a result of the development study prioritizes the storytelling method through empathic and reflective communication by the process of developing guided awareness. Therefore, this method has been verified as empirically effective through two phases of research, and therefore the emerging implications from the reality is the demand and calling for the teachers in classes, particularly the social studies teachers, to stimulate the learning through empathic-reflective communication strategy in developing the empathic awareness with guidance.

b. The consequences of the first implication is that it requires the spirit of integrity and sincerity that also derives from the most profound subconscious awareness to develop the learning strategy by building a multi direction empathic communication through the reduction of the domination of the teachers that are out of place and time, also providing the broadest space and opportunities to the students in order to grow a natural empathic awareness in an empathic communication climate among the students and the teachers. 
c. The effectiveness of the learning development through this model creates a greater implication of affective aspects in social studies learning, particularly for the purpose of empathic awareness learning for students.

d. This empathic awareness learning model contains substantial content, concept, and procedures that are quite simple, and therefore, it is easily adopted by the teachers. Nonetheless, getting accustomed to something that is yet habituated, requires willpower, integrity and sincerity in an earnest adjustment. For that reason, the implication is to continuously develop a spirit of innovation. The elementary teachers' forum can serve as a device to common teaching.

\section{Recommendations}

Based on the findings of this research, therefore several suggested recommendations are as follows:

\section{Recommendations for Model Implementations}

In order to implement this model, the followings are the recommendations:

a. Even though the research subjects, either in the first phase or second phase of development are fifth grade elementary students of various classes, yet this model is very recommended to be implemented in elementary students in various classes, even in the junior high school level of classes 7 and 8. For a lower or higher level, re-testing the significance is required. Nonetheless, the development phases are psychologically presumed to influence the findings of empathic awareness learning.

b. The practice of effective empathic awareness development in this model and can be continued to be implemented in the class. The utilized sample cases should be contextual and geographically adjacent with the students. Based on the findings, the cases from historical materials or the past can be recommended as consideration in selecting relevant cases for the development of empathic awareness. Empathy is a human mental attitude that exists throughout all eras.

c. In order to obtain optimum results in implementing this model, thus it is necessary to have a proper comprehension on the substantial content of the model, implementation procedure, and basic assumptions that are utilized basic and theoretical philosophies from the preparation of this model. This comprehension is recommended to prevent errors in the implementation done by the teachers or by other interested parties. Therefore, the forum of social studies teachers or other relevant communication forums can serve effectively as common teaching forums that include understanding important essences in the implementation of this model.

\section{Recommendations for Further Studies}

Further studies can be conducted based on the opportunities that surface from the findings of this study, either research consisting of expansion of the scope of the study, or follow up of this study. 


\section{REFERENCES}

Abidin, Z. ( 2000). Filsafat Manusia. Bandung: PT Remaja Rosda Karya.

Anasti, A and Susana U. (1988), Psychological Testing. New Jersey: PresticeHall, In

Armstrong, T. (2002). Sekolah Para Juara: Menerapkan Multiple Intelligences di Dunia Pendidikan. Penerjemah Y Murtanto, Bandung: KAIFA.

Baharuddi, H dan Makin. (2007). Pendidikan Humanistik. Jogyakarta: Ar-Ruzz Media.

Banks, J. A and Ambrose A. Clegg, Jr. (1985). Teaching Strategies for the Social Studies. New York: Longman.

Behl, S. (2005). Moral Stories: Stories for Budding Minds. New Delhi: Book Search. Part 1 and 2.

Bénabou, R and Jean, T. (2005). Incentives and Prosocial Behavior. National

Bureau of Economic Research, 1-7. Retrieved April 9, 2008, from NBER Working Paper Series.

Bloom, B.S.(1986). Taxonomy of Educational Objectives: Book I Cognitiive Domain. New York: Longman.

Bocker, R. L. (2003). Prosocial Behavior. Center on Philanthropy at Indiana University, (pp. 1-3).

Bourdillon, H. (1999). Teaching History. London. Routledge.

Brannen, J. (2002). Memadu metode penelitian. Alih Bahasa oleh Nuktah , A.K, Dkk. Cetakan Ke-3. Jogyakarta: Pustaka Pelajar.

Bratal, D. (1977). Prosocial Behavior: Theory and Research. Washington DC: Hemisphere Publishing co.

Brigham, J.C. (1991). Social Psichology. New York:Harper-Collins Publisher.2nd. Ed.

Brophy, J and Janet A.(1996). Powerful Social Studies For Elementary Students. San Diego: Harcourt Brace College Publishers.

Budiningsih. C.A. (2004). Pembelajaran Moral. Jakarta: PT Rineka Cipta.

Campbell, 1., B. Campbell dan D. Dickinson. (2004). Teaching and Learning Through Multiple Intelligencies. Third edition. Boston: pearson education, inc.

Carlo, G, Marcia S. Da Silva, Eisenberg, Frohlich, and Koller. (1996). A CrossNational Study on the Relations Among Prosocial Moral Reasoning, Gender Role Orientations, and Prosocial Behaviors. Developmental Psychology (Vol. 32, No. 2, pp. 2231-240).

Cartledge, G \& J.F Milburn. (1995). Teaching Social Skills to Children and Youth. London: Allyn and Bacon.

Coles, R. (2003). Menumbuhkan Kecerdasan Moral pada Anak. Jakarta: PT Gramediapustaka Utama.

Cooper, H. (1995). History in the Early Years. London: routledge.

Copp, D. (2001). Moral . Normativity, and Society. New york: Oxford University press. 
Cremers, A. (1995). Tahap-Tahap Perkembangan Moral. Yogyakarta: Penerbit Kanisius.

Creswell , J.W. (1994). Research Design: Qualitative \& Quantitative Approach. Thousand Oaks: Sage Publication.

Dahana, R.P. (2001). Menjadi Manusia Indonesia. Yogyakarta: LKIS.

Decety, J and William I. (editor). (2011). The Social Neuroscience of Empathy. Massachustts: A Bradford Book the MIT Press.

Departemen Pendidikan dan Kebudayaan Dirjen Dikdasmen .(1996). Metodik Khusus Pengajaran IPS di SD. Jakarta: Depdikbud.

Departemen Pendidikan Nasional.(2001). (Buku I). Konsep Pendidikan Kecakapan Hidup (life Skill Education). Jakarta: Depdiknas.

Departemen Pendidikan Nasional.(2001). (Buku II). Pola Pelaksanaan Broad Base Edducation (BBE). Jakarta: Depdiknas.

Departemen Pendidikan Nasional. (2007). Kurikulum Tingkat Satuan Pendidikan. Jakarta: Depdiknas.

Dewantara, K. H. (1967). Kebudayaan. Jogyakarta: Madjelis Luhur Persatuan Taman Siswa.

Dewantara, K. H. (1977). Pendidikan (edisi kedua). Jogyakarta: Madjelis Luhur Persatuan Taman Siswa

Dewey, J. (2004). Experience and Education. Pengantar Sudarminta. Terjemahan. Jakarta: Teraju.

Doddington, C dan Hilton, M. (2010). Pendidikan Berpusat pada Anak : Membangkitkan

Kembali Tradisi Kreatif. Jakarta: PT Indeks.

Drijarkara, s.j. (1966). Percikan Filsafat. Djakarta: Pembangunan.

Drost, J.Sj. (1999). Proses Pembelajaran sebagai Proses Pendidikan. Jakarta: PT Gramedia Widiasarana Indonesia .

Egan, K. (1988). Teaching is Storytelling: An Alternative Approach to Teaching and the

Curriculum. London and new york: routledge.

Egan, K. (1990). Romantic Understanding: the Development of Rationally and Imagination, Ages 8 to 15. London: routledge.

Elliott, J. (1991). Action Research for Educational Change. Milton Keynes: Open University Press.

Erikson ,E.H. (1964). Childhood and Society .New York: Norton.

Etzioni, E-Halevy. (1981. Social Change:The Advent And Maturation Of Modern Society. London:Routledge \& Kegan Paul Ltd

Fakih, M,DR dan Robert Chambers. (2002). Anak-Anak Membangun Kesadaran Kritis. Alih Bahasa H. Prabowo dan Nur Cholis. Yogyakarta: Read Book.

Fishbein, M and Icek A,.(1975). Belief, Attitude, Intention, and Behavior. Massachustts: Addison Wesley Publishing Company.

Feldman, R. S. (1989). Essentials of Understanding Psychology. New York: Mc Graw-Hill, Inc. 
Fraenkel, J.R. (1980). Helping Student Think and Value. Engelwood Cliffs: Prentice -Hall.

Fred, E. J. (1998). Intercultural Communication. London: SAGE Publication. Fromm, E. (1997). To Have or To Be?. London-New York: Continuum.

Gagne,R. M., et al. (1992). Principles of Instructional Design. New York: Harcourt Brace J. Ovanovich College Publishers.

Gall, M.D. Gall and Borg. (2003). Educational Research.. Boston: Pearson Education Inc. Seventh Edition.

Gazda, G.M, et al . (1991). Human Relations Development: A Manual for Educators. (4th ed). Boston: Allyn \& Bacon.

Gibran, K. (2002). Cinta, Keindahan, Kesunyian. Jogyakarta: Yayasan Bentang Budaya.

Giddens, A. (2001). Tumbal Modernitas Ambruknya Pilar-pilar Keimanan. Penerjemah M. Yamin. Yogyakarta: IRCiSoD.

Goleman, D. (1995). Emotional Intelligence. Alih bahasa T Hermaya. 1997. Jakarta: Gramedia Pustaka Publishers.

Gordon, M. (2009). Roots of Empathy. New York: The Experiment.

Håkansson, J., \& Montgomery, H. (2003). Empathy as an interpersonal phenomenon. Journal of Social and Personal Relationships, 20(3), 267-284.

Hardaniwati, M. et all (2003) Kamus Pelajar Sekolah Menengah Lanjutan Tingkat Pertama, Jakarta: Pusat Bahasa, Depdikbud.

Harisson, J. (1991). Understanding Children: Towards responsive Relationships. Selangor. S.Abdul Majeed \& Co.

Harrison, E. L dan Huntington. S.P. (2006). Kebangkitan Peran Budaya. Jakarta: LP3ES.

Harrow, A.J. (1972). A Taxonomiy of the Psychomotor Domain. New York: Longman

Hasan, H. (1996).Pendidikan Ilmu Sosial. Jakarta : Depdikbud.

Hasan, I. (2009). Analisis Data Penelitian dengan Statistik. Jakarta: Bumi Aksara.

Hatten, K. J and Rosenthal. S.R. (2001). Reaching For The Knowledge Edge . New York: Amacom.

Heidegger, M. (1962). Being in Time. Oxford: Basil Blackwell.

Hoodless, P. (1998). History and English in the Primary School. London: Routledge.

Hoffman, L. M. (2007). Empathy and Moral Development. New York: Cambridge University Press.

Hoffman, M. L. (1978). «Empathy, Its Development and Prosocial Implications», in C. B Keasey (ed.), Nebraska Symposium on Motivation , 25: 169-218.

Hopkins, D. (1993). A Teacher `s Guide To Classroom Research . Buckingham: Open University Press.

Hurlock, E.B. (1992). Perkembangan Anak. Jakarta: Erlangga.

Husband, C. (1996). What is History Teaching. Buckingham: Open University Press. 
Ibrahim , I.S. (2004). Dari Nalar Keterasingan menuju Nalar Pencerahan. Jogyakarta:

Jalasutra.

Iyengar, K.R.S.(2003 ). Rabindranath Tagore. enerjemah Abd Muhid. Jakarta: Pedati.

Jackson, M.A . (2003 ). Life lesson From History`s Heroes . London : Arrow Books.

Jacobs, L., Cheser and Clinton IC. (1992). Developing and Using Tests Effectively. California: Jossey-Bass Publishers.

Jarolimek, J and Clifford D. F, Sr. (1990) Teaching and learning In Elementary School. New York: Macmillan Publishing Company.

Joice, B and Weil. M. (1980). Models Of Teaching . New Jersey: Prentice Hall, Inc. Second Edition.

Kammeyer, K.C.W. Ritzer, G and Yetman, N.R. (1992) Sociology (fifth ed). Boston: Allyn and Bacon.

Kansil, C.S.T. (2003). Pancasila Dan Kewarganegaraan. Jakarta: PT Pradnya Paramita.

Knicker , PLA., Dovidio,. Piliavin, and Schroeder. (2005). Prosocial Behavior: Multilevel Perspectives. Annual Review of Psychology (Vol. 56, pp. 365-392). Kurikulum Tingkat Satuan Pendidikan 2006. (2007). Standar Kompetensi dan Kompetensi Dasar, Jakarta: BSNP, Depdiknas.

Kurtines M W and Gerwitz. J.L. (1993). Moralitas, Perilaku Moral, dan Perkembangan Moral. Penerjemah M.I Soelaeman.J akarta: UI Press.

Kusmarni. (2002). Pengaruh Bentuk Tes Objektifterhadap Kemampuan Berpikir Kritis dalam Pendidikan Sejarah ditinjau dari Sikap Siswa. Jakarta: Program Pasca Sarjana UNJ.

Krathwohl,. Bloom and Masia. B.B. (1964). Taxonomy of Educational Objectives: Affective Domain. New York: Longman.

Lapp, D, et al., (1985). Teaching and Learning. New York: Macmillan Publisher Co. Inc.

Lavine, T.Z .( 2002). Dari Socrates Ke Sartre. Jogyakarta: Penerbit Jendela.

Leahy, L. (2002). Horison Manusia: Dari Pengetahuan Ke Kebijaksanaan. Yogyakarta: Kanisius.

Lee, P. (1991). Historical Knowledge and the National Curriculum. London: Kogan Page.

Loomans , D and Loomans, J. (2003). 100 Ways To Build Self- Esteem and Teach Value.California: H.J. Kramer and New World Libarry.

Maslow, H.A. (1984). Motivasi dan Kepribadian: Teori Motivasi dengan Ancangan Hirarki Kebutuhan Manusia. Terjemahan Nurul Iman. Jakarta: PT Pustaka Binaman Pressindo.

Majid, A.Z. (2001). Mendidik dengan Cerita. Bandung: PT Remaja Rosdakarya.

Mangunwijaya,Y.B.(1999). Manusia Pasca Moderen, Semesta, dan Tuhan: Renungan Filsafat Hidup Manusia Moderen. Yogyakarta : Kanisuius. 
Megawangi, R. (2004). Pendidikan Karakter. Jakarta: Indonesian Haritage Foundation

Mehrabian, A., \& Epstein, N. (1972). A measure of emotional empathy. Journal of Personality, 40, 525-543.

Mehrens W.A. and Lehmann.(1985). Meassurement andEvaluation in Education and Psychology New York: Holt, Rinehart and Winston.

Miall.H, R.O and Woodhouse. (2000). Resolusi Damai Konflik Kontemporer. Penerjemah Tri Budi Satrio.Jakarta: Raja Grafindo Persada.

Muchtar, S.A. (2004). Pengembangan Berfikir Dan Nilai Dalam Pendidikan IPS. Bandung: Gelar Pustaka Mandiri.

Mueller, Daniel.(1986). Measuring Social Attitude.New York:Teachers College Press.

Mulyana, R. (2004). Mengartikulasikan Pendidikan Nilai. Bandung: Alfabeta.

Muthahhari, M. (1994). Manusia Sempurna: Pandangan Islam Tentang Hakekat Manusia. Terjemahan M. Hashem. Jakarta: Penerbit Lentera.

Nashori, F.H. (2003). Potensi - Potensi Manusia. Yogyakarta: Pustaka Pelajar.

Nasution, S. (1987). Berbagai Pendekatan dalam Proses Belajar dan Mengajar. Jakarta: PT Bina Aksara.

Noor syam, M. (1988). Filasafat Pendidikan Dan dasar Filsafat Pendidikan Pancasila .

Surabaya: Usaha Nasional.

O`Hara, L and O`Hara. (2001). Teaching History 3-11.London: Continuum.

O`Neil , W. F. (2003). Ideolog-Ideologi Pendidikan. Yogyakarta : Pustaka Pelajar.

Pai, Y. (1990). Cultural Foundations of Education . New York: Macmillan Publishing Company.

Papalia, D. E and Olds. (1992). Human Development. New York: McGrawwHill, Inc . Fifth Edition.

Penner, L.A., J. F. Dovidio, Piliavin, and Schroeder. (2005). Prosocial Behavior: Multilevel Perspectives. Annual Review of Psychology (Vol. 56, pp. 365392).

Peursen, C.A . (1980). Orientasi Di Alam Filsafat . Diterjemahkan oleh Dick Hartoko. Jakarta: Gramedia.

Peraturan Menteri Pendidikan Nasional RI No 23 tahun 2006. (2007) Standar Kompetensi Lulusan, Jakarta: BSNP, Depdiknas.

Peraturan Menteri Pendidikan Nasional RI No. 41 tahun 2007. (2007) Standar Proses untuk Satuan Pendidikan Dasar dan Menengah: BSNP, Depdiknas.

Permendiknas RI No.40.(2007).Standar Proses Untuk Satuan Pendidikan Dasar dan Menengah. Jakarta: Badan Standar Nasional Pendidikan.

Rakhmat, J. (1996). Psikologi Komunikasi. Bandung: PT Remaja Rosdakarya. Rich, J. M. (1971). Humanistic Foundations Of Education . Washington: Charles A.Jones Publishing Campany.

Rumi, J. (1977). The Mathnawi of Jalalu 'ddin Rumi . London: Nicholson , Luzac \& Co. 
Sagala, S. (2007). Konsep dan Makna Pembelajaran, Bandung: Alfabeta.

Sahgal, Abha.(2005). Awareness: Enviromental Sutdies . New Delhi: S.Chand \& Company.

Sanderson, K.S. (1993). Sosiologi Makro: Suatu Pendekatan Terhadap Realitas Sosial. Jakart: Rajawali Pers. Edisi Kedua.

Santrok .J.W. (2008). Educational Psichology Theori in to Practice. New York:

Mc Graw - Hill International Edition. $3^{\text {th. Ed. }}$

Saiyidain, K.G. (1981). Filsafat Iqbal mengenai Pendidikan. Alih Bahasa M.I Soelaeman. Bandung: CV Diponegoro

Savage, V. Tom and David G Armstrong.(1996). Effective Teaching in Elementary

Social Studies. New Jersey: Prentice-Hall Ink.

Simpson, B. and Willer. (2008). Altruism and Indirect Reciprocity: The Interaction of Persona and Situation in Prosocial Behavior. Social Psychology Quarterly (Vol. 71, pp. 37-50).

Sjarkawi.(2008). Pembentukan Kepribadian Anak: Peran Moral, Intelektual, Emosional, dan Sosial sebagai Wujud Inegritas Membangun Jati Diri. Jakarta : Bumi Aksara

Schiller, P and Bryant, T. (2002). 16 Moral Dasar BagiAnak. Alih Bahasa Susi Sensusi. Jakarta: PT. Elex Media Komputindo.

Schneider, D., et.al. (1994). Curriculum Standars For Social Studies Expectations of Excelence. New York: NCSS.

Semiawan, C. (2008). Belajar dan Pembelajaran Prasekolah dan Sekolah Dasar. Jakarta: PT Indeks.

Sihabuddin, R.,(2002). Pendidikan Demokrasi Melalui Pengelolaan Asertivitas dan Atribusi Siswa terhadap Sikap dan Perilaku Berdemokrasi. Bandung: Program Pascasarjana UPI.

Simon, S.B, Howe and Kirschenbaum. (1972). Values Clarification. New York: Hart Publishing Company, Inc.

Skeel, D.J. (1995). Elementary Social Studies. Harcourt Brace College Publishers.

Soelaeman, M.I. (1988). Suatu Telaah Tentang Manusia-Religi - Pendidikan. Jakarta: Depdikbud.

Skerritt, OZ. (1996). New Directions In Action Research. London: Falmer Press. Sudijono, A. (1987). Pengantar Statistik Pendidikan. Jakarta: PT Raja Grafindo Persada.

Sukirman, D. J, N. (2007). Perencanaan Pembelajaran. Bandung: UPI PRESS Sukmadinata, N.S. (2005). Metode Penelitian Pendidikan. Bandung: Rosda. Sumaatmadja, N. (1984). Metodologi Pengajaran IPS. Bandung: Penerbit Alumni.

Sumaatmadja, N. H. (2002). Pendidikan Pemanusiaan Manusia Manusiawi. Bandung: Alfabeta.

Sumaatmadja, N. (1996). Manusia Dalam Konteks Sosial, Budaya dan Lingkungan Hidup.Bandung: Alfabeta. 
Sunaryo.(1999).StrategiBelajarMengajardalamPengajaranIlmuPengetahuan Sosial, Jakarta: Depdikbud.

Sumohadiwidjoyo, S. (1975). Susila Budhi Dharma. .Swindon (England): Subud Publications International.

Syamsuddin, A. (2007). Psikologi Kependidikan. Bandung: PT. Remaja Rosda Karya.

Takwin, B. (2005). Kesadaran Plural: Sebuah Sintesis Rasionalitas Dan Kehendak Bebas. Jogyakarta: Jalasutra.

Thibaut, J.W. and Kelley. (1989). The Social Psychology of Groups. New York: Johm Wiley and Sons

Tilaar, H.A.R. (2002). Pendidikan, Kebudayaan dan Masyarakat Madani Indonesia: Strategi Reformasi Pendidikan Nasional. Bandung: PT Remaja Rosdakarya

Tillman, D. (2004). Living Values Activities For Chlidren Ages 8- 14. Jakarta: Grassindo.

Tuhuleley, S.A, Marup. dan Nasir. (2003). Masa Depan Kemanusiaan. Jogyakarta: Jendela.

Undang-Undang No. 20 Tahun 2003. (2003). Tentang Sistem Pendidikan Nasional: Bandung, Fokus Media.

Van Cleaf, D.W. (1991). Action in Elementary Social Studies. Boston: Allyn and Bacon.

Wardana, D., Basri, Y., Imran, A. (1997). Ilmu Pengetahuan Sosial Untuk Sekolah Dasar Kelas 5, Jakarta: Depdikbud.

Wiersma, W and Jurs. (1990). Educational Meassurement and Testing Needham Heights, Massachusettes: Allyn and Bacon.

Whitebread, D. (2000). The Psychology Of Teaching And Learning In The Primary School. London: Routledge\& Falmer.

Widiastoro, D.T (editor).( 2004). Pendidikan Manusia Indonesia. Jakarta: Penerbit Buku

Wirawan, S. 2002. Optimalisasi Kecerdasan Ganda dalam Era Informasi dan Globalisasi. Yogjakarta: PPS UNY

Wiriaatmadja, R. (2005). Metode Penelitian Tindakan Kelas. Bandung: Rosda. Wora, E. (2006). Perenialisme. Yogjakarta: Kanisius.

Wright,C. (1996). Navigating New Direction for Social Studies in New Founland and Labrador. Canadian Social Studies (Vol 31,No1:hal 16-21).

Zainul, A dan Nasution. (1993). Penilaian Hasil Belajar. Jakarta: Dirjen Dikti Zuchdi, D. (2008). Humanisasi Pendidikan : Menenmukan Kembali Pendidikan yang Manusiawi. Yogyakarta: PT Bumi Aksara. 